\title{
Włączenie studentów doświadczających kryzysów zdrowia psychicznego do pełnego uczestnictwa w społeczności akademickiej na przykładzie projektu „Przyjazny Uniwersytet" realizowanego na Uniwersytecie Marii Curie-Skłodowskiej w Lublinie
}

Katarzyna Skalska $\mid \begin{aligned} & \text { Wydział Pedagogiki i Psychologii, Instytut Pedagogiki, } \\ & \text { Uniwersytet Marii Curie-Skłodowskiej w Lublinie }\end{aligned}$

\section{Streszczenie}

Słowa kluczowe:

kryzys zdrowia psychicznego, student, społeczność akademicka

Obecność studentów doświadczających kryzysów zdrowia psychicznego nie jest zjawiskiem nowym w przestrzeni edukacyjnej, jednak w dzisiejszych czasach można wyraźniej zauważyć wyzwania, stojące pod tym względem przed społecznością akademicką. Obok pytań praktycznych związanych z procesem dydaktycznym i tworzeniem właściwych procedur na uczelniach warto zastanowić się nad tym, w jaki sposób włączyć studentów chorujących psychicznie w nurt życia akademickiego.

By spełnić to zadanie, Uniwersytet Marii Curie-Skłodowskiej od roku akademickiego 2013/2014 realizował projekt "Przyjazny Uniwersytet", którego pierwotnym celem było stworzenie przyjaznej przestrzeni edukacyjnej dla studentów doświadczających kryzysów zdrowia psychicznego. W ramach projektu na Uniwersytecie przeprowadzono wiele działań, które podniosły świadomość środowiska akademickiego na temat potrzeb tej grupy studentów. Zebrane w trakcie kolejnych lat akademickich doświadczenia projektowe wskazują, że kategoria Innego w edukacji obok wyzwań, które ze sobą niesie, może przyczynić się także do podniesienia jakości życia całej społeczności.

\section{Abstract}

Keywords:

Presence of students experiencing mental health issues in the academia is not a new phenomenon. The new aspect of this group's participation is greater visibility of the challenges that the academic community is facing. Challenges that not only raise practical questions related to the teaching process and creation of appropriate procedures at universities, but also task them with inclusion of students with mental health difficulties into the mainstream of academic life.

In order to accomplish this task, the Maria Curie-Sklodowska University initiated project "Friendly University” beginning in the 2013/2014 academic year. 
The initial goal of this project was to establish a friendly learning environment for students experiencing mental health issues. Numerous activities that increased academia's awareness in terms of such students' needs were carried out within the project, and at the same time they raised the question of mental hygiene. Project feedback and experiences gathered in subsequent academic years indicate that, despite challenges presented, they can also help to improve quality of academic life for the whole community, as in present form the project also includes work related to promoting mental health in the academia.

\section{Wstęp}

Celem niniejszego artykułu jest przedstawienie projektu „Przyjazny Uniwersytet”, realizowanego na Uniwersytecie Marii Curie-Skłodowskiej w Lublinie (UMCS) w latach 2013-2017. Projekt miał cel zarówno profilaktyczny, jak i edukacyjny. Podstawą do podjętych w nim działań były przeprowadzone badania dotyczące postrzegania osób doświadczających kryzysów zdrowia psychicznego w społeczności akademickiej, a także doświadczenia innych uczelni wyższych w zakresie tworzenia systemu wsparcia dla tej grupy studentów. W kolejnych etapach projektu - po zrealizowaniu celu związanego z wprowadzeniem rozwiązań wspierających studentów doświadczających kryzysów zdrowia psychicznego w procesie efektywnego studiowania - zostały podjęte działania uwrażliwiające społeczność akademicką na problematykę higieny zdrowia psychicznego.

\section{Tło teoretyczne projektu „Przyjazny Uniwersytet”}

Włączenie studentów doświadczających kryzysów zdrowia psychicznego do pełnego uczestnictwa w społeczności akademickiej jest wyzwaniem, które wiąże się z przemianami w samym systemie edukacji, a także ze zwiększającą się liczbą osób leczonych w Polsce z powodu zaburzeń psychicznych (Raport. Narodowy Program Ochrony Zdrowia Psychicznego 2016-2020. Rekomendacje). Raport podkreśla, że polskie społeczeństwo ma niski poziom świadomości społecznej w zakresie ochrony zdrowia psychicznego. Obywatele naszego kraju nie są w dostatecznym stopniu przygotowani do radzenia sobie z kryzysami życiowymi, zaś osoby potrzebujące wsparcia podlegają procesowi indywidulanej i strukturalnej stygmatyzacji, dyskryminacji oraz wykluczenia (Raport 2015: 7). Do niekorzystnej sytuacji osób doświadczających kryzysów zdrowia psychicznego w Polsce należy dodać - w przypadku studentów przeżywających takie kryzysy - konieczność funkcjonowania w środowisku o wysokich wymaganiach pomimo ograniczeń wynikających ze stanu zdrowia. By zdobyć wykształcenie wyższe, osoby te stają przed wyzwaniem efektywnego zarządzania wszystkimi 
aspektami swojego życia: od kwestii związanych z finansami po sprostanie zadaniom o charakterze intelektualnym. Środowisko akademickie jest mniej ustrukturyzowane niż szkoła średnia, a także jest w nim potencjalnie dużo różnego rodzaju dystraktorów (Smedema i in., 2015: 342). Studenci, którzy znajdują się pod opieką lekarza psychiatry, obok opisanych trudności podejmują także wysiłek, którego celem jest uniknięcie procesu stygmatyzacji. Narażenie na negatywne postawy społeczne może prowadzić do bezpośredniego odrzucenia społecznego lub „oczekiwania odrzucenia”, które przejawia się w postaci wstydu, zmiany koncepcji siebie, spadku samooceny, braku wiary w skuteczność własnych działań, a także zakłóconych interakcji z innymi i pogorszenia funkcjonowania społecznego (Świtaj 2008: 24). Przedstawione negatywne konsekwencje stygmatyzacji przyczyniają się do podniesienia poziomu stresu, a tym samym do zwiększonego ryzyka wystąpienia kolejnych zaburzeń.

Bruce G. Link (za: Świtaj 2008: 24) wyróżnił trzy strategie, które mają pomóc jednostce $w$ radzeniu sobie $z$ procesem stygmatyzacji: 1) utrzymywanie leczenia psychiatrycznego w tajemnicy; 2) wycofanie się z kontaktów, które mogą być przeżywane jako zagrożenie; 3) edukowanie, którego celem jest wpływanie na innych. Dwie pierwsze strategie wyróżnione przez badacza są zgodne z medycznym modelem niepełnosprawności, zaś strategia edukowania jest działaniem, które wpisuje się w społeczny model niepełnosprawności. Zadaniem społeczeństwa $w$ tym modelu jest włączenie osób z dysfunkcją do głównego nurtu życia społecznego w oparciu o zasady powszechności, wszechstronności, znormalizowania i równości (Kijak 2012: 23).

Realizacja społecznego modelu niepełnosprawności wpisuje się także w cele edukacji na poziomie wyższym. Wśród nich - obok budowania zdolności do krytycznego myślenia, do bycia obywatelem świata - jest rozwijanie "narracyjnej wyobraźni”, która pozwala na umiejętność dostrzegania marginalizowanych i wykluczonych osób z zachowaniem świadomości, że zawsze istnieje realna możliwość zmiany miejsc. Narracyjna wyobraźnia pozwala na rozwinięcie u młodzieży akademickiej postawy empatii, wrażliwości i pokory (Nowak-Dziemanowicz 2012: 4).

Postrzeganie doświadczenia inności i relacji z Innym może wnosić pozytywne aspekty do projektów o charakterze edukacyjnym. Szczególną wartością jest dostrzeżenie różnic, co pozwala na przekraczanie granic, wkraczanie w nowe obszary, a także wskazywanie na inne interpretacje oswojonego świata (Rzeźnicka-Krupa 2013: 44). Podobnie o kontakcie z Innym pisze Jerzy Nikitorowicz (1995: 41), podkreślając, że wychowanie człowieka polega na pomocy w przekształceniu kategorii odmienności i inności z kategorii zagrożenia, wrogości, nienormalności na kategorię interesującą, stymulującą, pomocną w zrozumieniu człowieka i świata. Antoni Kępiński (za: Cechnicki, Liberadzka 2015: 6), pisząc o spotkaniu z osobami chorującymi na schizofrenię, podkreśla, że takie spotkanie rzuca światło na pytania egzystencjalne, które są ważne zarówno dla osób zdrowych, jak i chorych, a także konfrontuje ludzi z dylematami ważnymi dla wszystkich. 
Młodzi dorośli stają wobec dylematów związanych z decyzjami życiowo ważnymi, które liczni badacze określają mianem kryzysu rozwojowego. Kryzys w tym sensie oznacza punkt zwrotny, rozstrzygający okres, w którym jednostka dysponuje zwiększonym potencjałem rozwojowym. Pojawiają się one na każdym etapie życia. W okresie wczesnej dorosłości jednostka dokonuje wyboru pomiędzy intymnością a samotnością. Gdy ten kryzys nie zostanie rozwiązany, wtedy człowiek opiera swoje relacje z ludźmi na zasadzie izolacji, ochrony własnego terytorium i intymności (Klimkowska 2010: 14). W świetle powyższych rozważań włączenie studentów doświadczających kryzysów zdrowia psychicznego do pełnego uczestnictwa w społeczności akademickiej nie może ograniczyć się wyłącznie do sfery dostosowania procesu dydaktycznego - powinien on także obejmować te sfery życia studentów, które uwzględniają zadania rozwojowe okresu wczesnej dorosłości. By zmniejszyć dystans pomiędzy studentami z zaburzeniami i chorobami psychicznymi a studentami z grupy rówieśniczej, na potrzeby projektu zostało przyjęte pojęcie studenta doświadczającego kryzysów zdrowia psychicznego. Pojęcie kryzysu w psychologii jest pojęciem negatywnym, przejściowym. Gerald Caplan (za: Sęk 1991: 23) podkreślał, że kryzys może być szansą na rozwój, a jednocześnie wiązać się z podwyższoną reakcją na zranienie. Autor ten opisał kryzys w czterech fazach:

1. Wzrost napięcia i podejmowanie prób w celu znalezienia rozwiązania.

2. Podejmowane próby okazują się mało efektywne - dochodzi wtedy do dalszego wzrostu napięcia.

3. Następuje mobilizacja ostatecznych rezerw, a także ostateczne rozwiązanie problemu. W sytuacji tej dochodzi do emocjonalnego i poznawczego przekształcenia sytuacji problemowej.

4. Dochodzi do kulminacji w sytuacji kryzysowej, a tym samym w zachowaniu jednostki mogą pojawić się niekorzystne zmiany.

Kryzys jest pojęciem wspólnym zarówno dla psychologii klinicznej, społecznej, jak i psychologii rozwojowej, a także pojęciem centralnym dla działalności prewencyjnej w zakresie zdrowia psychicznego (Sęk 1991: 23). Profilaktyka zaburzeń psychicznych wśród młodzieży akademickiej jest istotna z punktu widzenia początku ich przebiegu. Większość zaburzeń ma swój początek w okresie przełomowym pomiędzy okresem dojrzewania a okresem wczesnej dorosłości. Do przyczyn, które mogą powodować wystąpienie pierwszych symptomów zaburzeń psychicznych wśród młodzieży akademickiej, należą: przejście rozwojowe pomiędzy okresami, zmiany życiowe wynikające z rozpoczęcia studiów, zmiana otoczenia, większa odpowiedzialność finansowa, nowy system kształcenia, a także relacje uczuciowe (Nowak-Adamczyk 2014: 76). 


\section{Badania przeprowadzone w ramach projektu „Przyjazny Uniwersytet”}

Pierwszym działaniem, które zostało podjęte w ramach projektu, było przeprowadzenie badania na temat postaw studentów i pracowników wobec osób doświadczających kryzysów zdrowia psychicznego. Stanowiło to podstawę do podejmowania dalszych działań w projekcie. Wśród studentów przeprowadzono ankietę online, zaś wobec pracowników zastosowano metodę wywiadu pogłębionego. Przebadanych zostało 209 studentów i doktorantów UMCS (Sprawozdanie z badań w ramach projektu „Przyjazny Uniwersytet"), a także 22 pracowników naukowych i administracyjnych (każdy wydział uniwersytetu był reprezentowany przez pracownika naukowego i administracyjnego). Główne obszary badawcze odnosiły się do wiedzy z zakresu zdrowia psychicznego i stosunku do studentów doświadczających kryzysów zdrowia psychicznego, zaś w grupie pracowniczej koncentrowano się na diagnozie wiedzy pracowników o trudnościach w funkcjonowaniu akademickim i wyrównywaniu szans tej grupy studentów.

W badaniu 61\% studentów odpowiedziało, że chcieliby poszerzyć swoją wiedzę z zakresu zdrowia psychicznego. Podobny procent osób badanych deklarował, że chce poszerzyć swoją wiedzę z zakresu dbania o własne zdrowie. Znajomość sposobów dbania o własne zdrowie była najrzadziej deklarowana przez studentów pierwszego roku.

W zakresie przekonań na temat osób z zaburzeniami psychicznymi studenci przypisywali takim osobom tendencje aspołeczne, jednocześnie połowa badanych odpowiedziała, że nie wie, czy kontakt z osobą zaburzoną psychicznie może mieć pozytywne skutki. Wśród badanych 7\% uważało, że nie ma pozytywnych skutków w takich kontaktach, zaś 39\% respondentów odpowiedziało, że taki kontakt może wzbogacać intelektualnie poprzez wiedzę o naturze psychiki ludzkiej i zaburzeniach psychicznych, ponadto kontakt z drugim człowiekiem podnosi wrażliwość na jego potrzeby, czyli według badanych rozwija empatię, współczucie oraz gotowość do niesienia pomocy. Ostatnią motywacją przedstawioną przez badanych była korzyść w postaci oceny własnego zdrowia, a także zwiększonej chęci do pracy nad sobą. Na pytanie dotyczące negatywnych skutków wynikających z kontaktu z osobą cierpiącą na zaburzenie psychiczne $56 \%$ badanych odpowiedziało, że takowych nie dostrzega. Wśród badanych $27 \%$ obawiało się negatywnych konsekwencji takiego kontaktu, a szczególnie: agresywnego, negatywnego i nieprzewidywalnego zachowania, ataku fizycznego lub psychicznego, a także nadmiernego zaangażowania, które odbędzie się kosztem osobistych planów. Obawy dotyczyły również negatywnych stanów emocjonalnych, które mogłyby wpływać na ich własne samopoczucie.

W badaniach zostały wyłonione podmioty, które wśród społeczności akademickiej cieszą się największym zaufaniem w zakresie przekazania informacji o własnym stanie zdrowia, tak by otrzymać odpowiednią pomoc na uczelni. Były to: Zespół ds. Osób 
Niepełnosprawnych (42,1\%), opiekun roku (34,9\%), dziekan ds. studenckich $(28,7 \%)$, zaś pracowników dziekanatu wskazywało 15,3\% badanych. Zespół ds. Osób Niepełnosprawnych cieszy się wysokim zaufaniem być może dlatego, że jest postrzegany jako jednostka niosąca pomoc, nie będąca jednocześnie we władzach uczelni.

Jedno z pytań dotyczyło możliwości poinformowania studenta, który doświadcza kryzysów zdrowia psychicznego, o obserwowanych u niego negatywnych objawach. Spośród badanych tylko 17\% poinformowałoby go o tym, że zauważyło objawy zaburzenia psychicznego. Swoją odpowiedź motywowali faktem, że wczesna interwencja może być pomocna w leczeniu, a osoba doświadczająca zaburzenia może nie zdawać sobie z tego sprawy. $Z$ kolei 34\% respondentów odpowiedziało „raczej tak", ale warunkowo zaznaczając, że mogliby poinformować osobę, którą dobrze znają, zaś $14 \%$ respondentów nie poinformowałoby znajomego, że dostrzega u niego pierwsze objawy zaburzeń psychicznych.

Obawy towarzyszące badanym osobom w związku z rozmową o obserwowanych trudnościach psychicznych u rówieśników to:

- obawa przed pomyłką,

- obawa przed negatywną reakcją,

- obawa przed wyrządzeniem komuś krzywdy.

Pracownicy UMCS w wywiadach pogłębionych przyznawali, że najczęściej mają kontakt ze studentami, którzy cierpią z powodu depresji. Potrafili także wymienić trudności, jakich może doznawać student doświadczający kryzysów zdrowia psychicznego. Pracownicy naukowi koncentrowali się na trudnościach w procesie komunikacyjnym, zaś pracownicy administracyjni mówili o możliwości wystąpienia zachowań agresywnych. Obydwie grupy pracownicze podkreślały, że ważna jest postawa szacunku i podmiotowe traktowanie studenta, ale dostrzegają potrzebę szkoleń z zakresu psychopatologii.

Na podstawie wyników badań przeprowadzonych w ramach projektu „Przyjazny Uniwersytet" zostały wdrożone działania, których cele ogniskują się wokół:

- systemu wsparcia dla studentów doświadczających kryzysów zdrowia psychicznego,

- edukowania społeczności akademickiej z zakresu potrzeb osób doświadczających kryzysów zdrowia psychicznego,

- wydarzeń, których celem jest zwiększanie zasobów zdrowia psychicznego w społeczności akademickiej.

\section{Formy wsparcia dlla studentów doświadczających kryzysów zdrowia psychicznego w ramach projektu „Przyjazny Uniwersytet"}

Osoby doświadczające kryzysów zdrowia psychicznego w procesie studiowania narażone są na przeżywanie stresu i sytuacji lękotwórczych, które wynikają z konieczności 
spełniania konkretnych wymagań związanych ze sprawdzaniem wiedzy, ponadto narażone są na negatywne emocje związane z ekspozycją społeczną, na przykład oceną aktywności studentów na ćwiczeniach. Trudności w sferze edukacyjnej mogą rzutować na obawy w kontaktach interpersonalnych, w których student nie rozwija kompetencji społecznych - potrzebnych na obecnym etapie, a także w perspektywie przyszłej aktywności zawodowej (Podgórska-Jachnik, Pietras 2014: 156). W zakresie trudności w uczeniu się student może doświadczać następujących trudności: problemów z koncentracją i utrzymywaniem uwagi, pogorszenia pamięci, spowolnienia psychoruchowego, przyspieszonego toku myślenia, lęku przed publicznym wypowiadaniem się, perfekcjonizmu i nadmiernych wymagań, a także lęku przed przebywaniem w pomieszczeniach zamkniętych (Nowak-Adamczyk 2014: 76). Dorota Podgórska-Jachnik i Tadeusz Pietras (2014: 156) zestawienie to uzupełniają jeszcze o trudności z dostosowaniem się do terminów, sesją egzaminacyjną, która wiąże się z dużym obciążeniem, wpływem leków psychotropowych na pamięć i tempo pracy oraz obawą przed stygmatyzacją w środowisku akademickim. By odpowiedzieć na problemy studentów doświadczających kryzysów zdrowia psychicznego, zaproponowano poniżej przedstawione formy wsparcia na UMCS.

Studenci zostali przede wszystkim poinformowani o możliwości skorzystania z rozwiązań Regulaminu Studiów, na podstawie którego mogą ubiegać się o wydłużenie czasu egzaminu oraz przeniesienie egzaminu na termin bardziej dogodny czy urlop zdrowotny, w trakcie którego można uczestniczyć w wybranych zajęciach (Regulamin Studiów na Uniwersytecie Marii Curie-Skłodowskiej w Lublinie).

Dodatkowo studentom zostałyzaproponowane inne formy wsparcia psychologicznego:

- poradnictwo psychologiczne - jego celem jest pomoc w rozwiązywaniu bieżących problemów doświadczanych w czasie studiów,

- porady z zakresu efektywnego uczenia się - w ramach tych zajęć można ćwiczyć umiejętności związane ze zwiększeniem koncentracji uwagi, usprawnieniem procesów pamięciowych, zmniejszeniem napięcia związanego z ekspozycją społeczną,

- porady lekarza psychiatry - ich celem jest wyjaśnienie studentowi, jaki wpływ na proces uczenia się ma jego schorzenie oraz przyjmowane leki.

\section{Edukowanie społeczności akademickiej z zakresu potrzeb osób doświadczających kryzysów zdrowia psychicznego}

W relacjach ze studentami, którzy doświadczają kryzysów zdrowia psychicznego podobnie jak w przypadku studentów z niepełnosprawnością - istnieje niebezpieczeństwo odrzucenia poprzez zastosowanie mechanizmu tzw. kozła ofiarnego. Polega on na rozciąganiu jednego przykładu - gdy jakiś student „nie dał rady” lub oszukał kogoś - na całą grupę studentów, którzy mają trudności w funkcjonowaniu akademickim ze względu na stan zdrowia. W taki sposób następuje uogólnienie jednostkowego doświadczenia, które może przyczynić się do negatywnej oceny studiowania 
osób doświadczających kryzysów zdrowia psychicznego (Filek 2012: 19), dlatego tak ważne w omawianym projekcie były działania o charakterze szkoleniowym dla kadry akademickiej. Ich głównym zadaniem było dostarczenie pracownikom naukowo-dydaktycznym wiedzy o kryzysach psychicznych; prowadzono je cyklicznie przez wszystkie lata trwania projektu. Celem tych szkoleń było dostarczenie wykładowcom rzetelnej wiedzy z zakresu psychopatologii, były one także źródłem wiedzy o problemach i trudnościach, będących udziałem osób prowadzących zajęcia.

W wyniku potrzeb zgłaszanych przez osoby prowadzące zajęcia powstała broszura skierowana do nauczycieli akademickich: Przyjazny Uniwersytet. Wsparcie studentów doświadczających kryzysów zdrowia psychicznego. Przedstawiono w niej zasady komunikacji ze studentem na każdym etapie przebiegu choroby lub zaburzenia. Opracowanie wyznacza także standardy, jakimi powinien kierować się nauczyciel akademicki w pracy ze studentami doświadczającymi kryzysów zdrowia psychicznego.

Uwrażliwianie rówieśników studentów doświadczających kryzysów koncentrowało się również na zwiększaniu świadomości potrzeb tej grupy. Wykłady z psychopatologii prowadzone przez lekarzy psychiatrów dotyczyły zaburzeń i chorób psychicznych. Podobny cel spełniało „Psychokino”, łączące prezentację filmu z dyskusją specjalistów wokół zagadnień związanych ze zdrowiem psychicznym.

Dla społeczności studentów powstała także broszura: Wsparcie rówieśników doświadczajacych kryzysów zdrowia psychicznego. Celem przyświecającym autorom tego wydawnictwa było zachęcenie studentów do wsparcia rówieśników na każdym etapie rozwoju problemu psychicznego: od pojawienia się pierwszych objawów do wsparcia w procesie zdrowienia i powrotu na uczelnię po przerwie związanej z procesem leczenia.

\section{Działania zwiększające zasoby zdrowia psychicznego w społeczności akademickiej}

Zgodnie z literaturą przedmiotu do czynników, które warunkują prozdrowotny styl życia, należą: aktywny wypoczynek w czasie wolnym, grupa towarzyska, umiejętność łączenia aktywności zawodowej z innymi sferami życia, umiejętność radzenia sobie z napięciem, a także taka organizacja życia domowego, by było ono nakierowane na cele prozdrowotne (Ziółkowska 2005: 443).

Szczególnym działaniem zaproponowanym społeczności akademickiej, którego celem była promocja prozdrowotnego stylu życia, były Dni Higieny Psychicznej. W ich ramach dla studentów oraz pracowników UMCS zostały przygotowane szkolenia i wykłady, podnoszące wiedzę psychologiczną uczestników i motywujące do prozdrowotnego stylu życia. 


\section{Zakończenie}

W pierwszych latach realizacji projektu „Przyjazny Uniwersytet” koncentrowano się głównie na zagadnieniach związanych z chorobami i zaburzeniami psychicznymi oraz stworzeniem systemu wsparcia dla studentów doświadczających kryzysu zdrowia psychicznego, jednak w kolejnych podejmowanych działaniach zaczęto się koncentrować na promocji zdrowia psychicznego w społeczności akademickiej. Szczególnie istotny wydaje się wniosek, że działania o charakterze wspierającym ewoluowały w kierunku działań o charakterze projektowania uniwersalnego (Funckes: 2010: 9; Olechowska: 2016: 298). Uniwersalne projektowanie w edukacji jest odpowiedzią na różnorodność pomiędzy studentami, wyrażającą się w stylach uczenia, języku, doświadczeniach kulturowych, wieku i różnych doświadczeń życiowych.

\section{Literatura}

Cechnicki A., Liberadzka A., 2015, Wstęp, (w:), Umocnienie i zdrowienie. Daćnadzieję, red. A. Cechnicki, A. Liberadzka, Kraków: Wydawnictwo Uniwersytetu Jagiellońskiego.

Filek J., 2012, Studenci niepełnosprawni - nieporozumienia, lęki, odrzucenia, (w:) Student z niepełnosprawnościq w środowisku akademickim, red. K. Kutek-Słabek, Kraków: Wydawnictwo św. Stanisława BM Archidiecezji Krakowskiej.

Funckes C., 2010, Projektowanie uniwersalne: zastosowanie w szkolnictwie wyższym, (w:) Uniwersytet dla wszystkich. Uniwersalne projektowanie zajęć dydaktycznych, red. P. Wdówik, Warszawa: Biuro ds. Osób Niepełnosprawnych Uniwersytetu Warszawskiego.

Kijak R., 2012, Dorosłość i starość osób niepełnosprawnych - wprowadzenie, (w:) Niepełnosprawność w zwierciadle dorosłości, red. R. Kijak, Kraków: Oficyna Wydawnicza „Impuls”.

Klimkowska K., 2010, Funkcjonowanie społeczne młodzieży akademickiej, Lublin: Wydawnictwo Uniwersytetu Marii Curie-Skłodowskiej.

Nikitorowicz J., 1995, Pogranicze. Tożsamość. Edukacja międzykulturowa, Białystok: Wydawnictwo Uniwersyteckie Trans Humana.

Nowak-Adamczyk D., 2014, Studenci zzaburzeniami psychicznymi w przestrzeni akademickiej-system wsparcia edukacyjnego na Uniwersytecie Jagiellońskim w Krakowie, „Niepełnosprawność - zagadnienia, problemy, rozwiązania" nr 4.

Nowak-Dziemanowicz M., 2012, Kompetencje społeczne jako jeden z efektów kształcenia w Krajowych Ramach Kwalifikacji w kontekście pytań o cele i funkcje edukacji, Warszawa: Instytut Badań Edukacyjnych.

Olechowska A., 2016, Specjalne potrzeby edukacyjne, Warszawa: PWN.

Podgórska-Jachnik D., Pietras T., 2014, Praca socjalna z osobami z zaburzeniami psychicznymi i ich rodzinami, Warszawa: Centrum Rozwoju Zasobów Ludzkich.

Raport. Narodowy Program Ochrony Zdrowia Psychicznego 2016-2020. Rekomendacje, 2015, Warszawa: Obywatelska Koalicja na Rzecz Zdrowia Psychicznego.

Regulamin Studiów na Uniwersytecie Marii Curie-Skłodowskiej w Lublinie, http://phavi.umcs.pl/at/ attachments/2016/0525/131950-t-j-regulamin-studiow-umcs-z-dnia-22-kwietnia-2015-r-t-j.pdf [dostęp: 20.07.2017]. 
Rzeźnicka-Krupa J., 2013, Inny i pedagogika: doświadczenie inności i relacja z innym jako istotne kategorie nauk o wychowaniu, ",Studia Edukacyjne” nr 28.

Sęk H., 1991, Psychologiczna prewencja jako obszar badań i zastosowań, (w:) Zagadnienia psychologii prewencji, red. H. Sęk, Poznań: Uniwersytet im. Adama Mickiewicza.

Smedema S. M., Chan F., Yaghmaian R. A., Cardaso E. D., Muller V., Keegan J., Dutta A., Ebener D. J., 2015, The Relationship of Core Self-Evaluations and Life Satisfaction in College Students with Disabilities: Evaluation of a Mediator Model , ,Journal of Postsecondary Education and Disability" nr 28(3).

Sprawozdanie z badań w ramach projektu Przyjazny Uniwersytet, http://phavi.umcs.pl/at/attachments/2016/0525/131950-t-j-regulamin-studiow-umcs-z-dnia-22-kwietnia-2015-r-t-j.pdf [dostęp: 20.07.2017].

Sprawozdanie z projektu Przyjazny Uniwersytet Uniwersytet Marii Curie-Skłodowskiej w Lublinie Rok akademicki 2013/2014, http://phavi.umcs.pl/at/attachments/2015/1201/092448-sprawozdanie-z-pu-i.pdf [dostęp: 20.07.2017].

Sprawozdanie z Il edycji projektu Przyjazny Uniwersytet Uniwersytet Marii Curie-Skłodowskiej w Lublinie Rok akademicki 2014/2015, http://phavi.umcs.pl/at/attachments/2015/1201/092449-sprawozdanie-pu-ii.pdf [dostęp: 20.07.2017].

Sprawozdanie z III Edycji Projektu Przyjazny Uniwersytet Rok akademicki 2015/2016, http://phavi. umcs.pl/at/attachments/2017/0115/114331-sprawozdanie-z-projektu-przyjazny-uniwersytet-iii. pdf [dostęp: 20.07.2017].

Świtaj P., 2008, Doświadczenie piętna społecznego i dyskryminacji u pacjentów z rozpoznaniem schizofrenii, Warszawa: Instytut Psychiatrii i Neurologii.

Ziółkowska B., 2005, Okres wczesnej dorosłości. Jak rozpoznać potencjał młodych dorosłych? (w:) Psychologiczne portrety człowieka, red. A. I. Brzezińska, Gdańsk: Gdańskie Wydawnictwo Psychologiczne.

\section{Aneks}

\section{Pytania ankiety przeprowadzonej online wśród studentów UMCS:}

1. Czy czujesz się wystarczająco poinformowany / poinformowana w kwestii zdrowia psychicznego i zaburzeń psychicznych, czy też chciałbyś / chciałabyś dowiedzieć się czegoś więcej na ten temat?

2. Czy wiesz, jak należy dbać o własne zdrowie psychiczne?

3. Poniżej znajdują się określenia dotyczące zaburzeń psychicznych. Zaznacz na skali te odpowiedzi, które są najbardziej zgodne z twoimi przekonaniami (skala od 1 do 5):

- zaraźliwe vs. niezaraźliwe,

- uleczalne vs. nieuleczalne,

- nie są wstydliwe vs. są wstydliwe,

- wrodzone vs. nabyte.

4. Poniżej znajdują się określenia człowieka cierpiącego na zaburzenia psychiczne. Zaznacz na skali te odpowiedzi, które są najbardziej zgodne z twoimi przekonaniami (skala od 1 do 5):

- godny zaufania vs. niegodny zaufania, 
- zaradny vs. niezaradny,

- nie stanowi zagrożenia dla otoczenia vs. stanowi zagrożenie dla otoczenia,

- można na nim polegać vs. nie można na nim polegać,

- inteligentny vs. mało inteligentny,

- zwyczajny vs. dziwny,

- pracowity vs. leniwy,

- odpowiedzialny vs. nieodpowiedzialny.

5. Jakie znasz zaburzenia psychiczne? Wymień je.

6. Jakie znasz objawy zaburzeń psychicznych? Wymień je.

7. Jak uważasz, kto z otoczenia studenta powinien wiedzieć o jego problemach zdrowia psychicznego (skala: wszyscy, większość, trudno powiedzieć, tylko niektórzy, nikt):

- bliższa rodzina,

- dalsza rodzina,

- współlokatorzy,

- koledzy z roku,

- znajomi spoza uczelni,

- wykładowcy.

8. Jak uważasz, kto z pracowników uczelni powinien wiedzieć o problemach zdrowia psychicznego studenta (skala: zdecydowanie tak, raczej tak, trudno powiedzieć, raczej nie, zdecydowanie nie)?

- dziekan ds. studenckich,

- pracownik dziekanatu,

- opiekun roku,

- zespół do spraw osób niepełnosprawnych.

9. Gdyby stwierdzono u ciebie zaburzenia psychiczne, czy byłbyś skłonny / byłabyś skłonna do poinformowania o tym (skala: wszystkich, większość, trudno powiedzieć, tylko niektórych, nikogo):

- bliższą rodzinę,

- dalszą rodzinę,

- współlokatorów,

- kolegów z roku,

- znajomych spoza uczelni,

- wykładowców.

10. Jak uważasz, czy gdybyś cierpiał / cierpiała z powodu zaburzenia psychicznego, to byłbyś skłonny / byłabyś skłonna poinformować o tym pracowników uczelni (skala: zdecydowanie tak, raczej tak, trudno powiedzieć, raczej nie, zdecydowanie nie)?

- dziekana ds. studenckich,

- pracownika dziekanatu,

- opiekuna roku,

- zespół do spraw osób niepełnosprawnych. 
11. Wyobraź sobie sytuację, w której zauważasz u znajomego oznaki świadczące o zaburzeniu psychicznym. Czy w takiej sytuacji byłbyś gotowy / byłabyś gotowa powiedzieć mu o tym?

12. Czy z kontaktu z osobą cierpiącą na zaburzenia psychiczne mogą wypływać pozytywne skutki?

13. Czy uważasz, że kontakt z osobą cierpiącą na zaburzenia psychiczne może powodować negatywne skutki?

14. Pytanie dotyczy twojego stosunku do osób, które chorowały psychicznie i z tego powodu przebywały szpitalu psychiatrycznym. Określ, jak bardzo problematyczna byłaby dla ciebie każda z poniższych sytuacji (skala: zdecydowanie nie stanowiłaby dla mnie problemu, raczej nie stanowiłaby dla mnie problemu, raczej byłaby dla mnie problemem, zdecydowanie byłaby dla mnie problemem, trudno powiedzieć):

- w twojej grupie ćwiczeniowej jest taka osoba,

- dłuższa rozmowa z taka osobą,

- pożyczenie notatek takiej osobie,

- pomoc w nauce takiej osobie,

- wykonanie pracy grupowej z taka osoba.

- wyjście do kina z taka osobą,

- taka osoba jest twoim współlokatorem w mieszkaniu,

- taka osoba jest twoim bliskim znajomym,

- taka osoba jest twoim partnerem/ partnerką.

15. Czy znasz kogoś z zaburzeniami psychicznymi?

\section{Pytania do pracowników UMCS w wywiadzie pogłębionym:}

1. Czy uważa Pan / Pani, że zaburzenia psychiczne stanowią częsty problem u studentów?

2. Na jakie zaburzenia psychiczne Pana / Pani zdaniem najczęściej cierpią studenci?

3. Po czym pozna Pan / Pani, że student może mieć problemy natury psychicznej?

4. Czy Pana / Pani zdaniem na przestrzeni lat Pańskiej pracy zaszły jakieś zmiany w kwestii zdrowia psychicznego studentów?

5. Jak Pan / Pani uważa, jakie problemy w studiowaniu mają osoby cierpiące na zaburzenia psychiczne?

6. Czy spotkał Pan / spotkała Pani kiedyś studenta, o którym sądził Pan / sądziła Pani, że ma problemy natury psychicznej?

7. Co Pana / Pani zdaniem ze strony wykładowców i pracowników administracyjnych, mogłoby pomóc studentom cierpiącym na zaburzenia psychiczne w studiowaniu? 
8. Czy według Pana / Pani należy stworzyć procedury wyrównujące szansy studiowania osobom cierpiącym na zaburzenia psychiczne?

9. Czego oczekuje Pan / Pani od uczelni w kwestii kontaktów ze studentami cierpiącymi na zaburzenia psychiczne?

\section{Pytanie wyłącznie do pracowników naukowych:}

1. Czy chciałby Pan / chciałaby Pani wiedzieć o zaburzeniach psychicznych u swojego studenta?

2. Pytania o konkretne procedury: czy byłby Pan skłonny / byłaby Pani skłonna

- zmienić formę zaliczenia (pisemne / ustne) ze względu na stan zdrowia psychicznego studenta,

- przedłużyć czas zdawania materiału ze względu na stan zdrowia psychicznego studenta,

- umożliwić studentowi zdawanie materiału mniejszymi partiami ze względu na stan jego zdrowia psychicznego,

- czy uczelnia powinna pozwalać, by osoby cierpiące na zaburzenia psychiczne zaliczały część materiału podczas urlopu dziekańskiego?

\section{Pytania wyłącznie do pracowników administracyjnych:}

1. Czy uważa Pan / Pani, że osoba cierpiąca na zaburzenia psychiczne jest w stanie sprostać obowiązkom studenta?

2. Czy uważa Pan / Pani, że w sprawie zdrowia psychicznego studenta powinna obowiązywać zasada dyskrecji i ochrony danych osobowych?

3. Czy według Pana / Pani w punktach obsługi studenta powinna panować przyjazna atmosfera w stosunku do osób cierpiących na problemy zdrowia psychicznego?

4. Czy pracownicy administracyjni powinni wiedzieć o istnieniu Zespołu ds. Studentów Niepełnosprawnych, by móc odesłać tam osobę, u której podejrzewają problemy ze zdrowiem psychicznym?

5. Jak Pana / Pani jednostka mogłaby ułatwić załatwianie spraw przez studentów z zaburzeniami psychicznymi? 